\title{
Inhibition of Intracellular Cholesterol Transport Alters Presenilin Localization and Amyloid Precursor Protein Processing in Neuronal Cells
}

\author{
Heiko Runz,, ${ }^{1,2}$ Jens Rietdorf, ${ }^{2}$ Inge Tomic, ${ }^{1}$ Marina de Bernard, ${ }^{3}$ Konrad Beyreuther, ${ }^{1}$ Rainer Pepperkok, ${ }^{2}$ \\ and Tobias Hartmann ${ }^{1}$
}

${ }^{1}$ Center for Molecular Biology, University of Heidelberg, 69120 Heidelberg, Germany, ${ }^{2}$ European Molecular Biology

Laboratory, 69117 Heidelberg, Germany, and '3Department of Biomedical Science, University of Padua, 35121

Padua, Italy

Generation of amyloid- $\beta(\mathrm{A} \beta)$ from the amyloid precursor protein (APP) requires proteolytic cleavage by two proteases, $\beta$ and $\gamma$-secretase. Several lines of evidence suggest a role for cholesterol on secretase activities, although the responsible cellular mechanisms remain unclear. Here we show that alterations in cholesterol transport from late endocytic organelles to the endoplasmic reticulum have important consequences for both APP processing and the localization of $\gamma$-secretaseassociated presenilins (PS). Exposure of neuronal cells to cholesterol transport-inhibiting agents resulted in a marked decrease in $\beta$-cleavage of full-length APP. In contrast, $\gamma$-secretase activity on APP C-terminal fragments was enhanced, increasing the production of both $A \beta 40$ and $A \beta 42$. Remarkably, retention of cholesterol in endosomal/lysosomal compartments induced
PS1 and PS2 to accumulate in Rab7-positive vesicular organelles implicated in cholesterol sorting. Accumulation of PS in vesicular compartments was prominent in both Chinese hamster ovary cells deficient in Niemann-Pick C1 protein as well as in neuronal cells exposed to the cholesterol transportinhibiting agent U18666A. Because A $\beta 42$ also localized to PS1containing vesicular compartments, organelles involved in cholesterol transport might represent an important site for $\gamma$-secretase activity. Our results suggest that the subcellular distribution of cholesterol may be an important factor in how cholesterol alters $A \beta$ production and the risk of Alzheimer's disease.

Key words: presenilin; cholesterol; NPC1; APP processing; Rab7; ACAT; amyloid- $\beta$
Although its primary function in vivo remains unclear, it generally is accepted that amyloid precursor protein (APP) is processed sequentially by several proteolytic events. Cleavage of the fulllength precursor by $\alpha$-secretase creates $\mathrm{APP} \alpha$ sec, which is released into the medium, leaving behind a short membrane-bound $\mathrm{C}$-terminal fragment ( $\alpha \mathrm{CTF}$ ). Less frequently, the holoprotein is cleaved at a slightly more N-terminal site, generating $\beta \mathrm{CTF}$ and APP $\beta$ sec. APP CTFs can be processed further by $\gamma$-secretase. This second cleavage event occurs within the membrane region of the C-terminal stumps and requires the multi-transmembranespanning proteins presenilin 1 (PS1) or PS2. Cleavage at the $\gamma$-site of $\beta \mathrm{CTF}$ generates the $4 \mathrm{kDa}$ fragment amyloid- $\beta(\mathrm{A} \beta)$, which represents a major component of amyloid plaques in Alzheimer's disease (AD). Additional cleavage of $\alpha \mathrm{CTF}$ yields the nonamyloidogenic peptide p3 (for review, see De Strooper and Annaert, 2000).

Increasing evidence indicates a role for cholesterol in the metabolism of APP. Carriers of the ApoE4 allele of apolipoprotein $\mathrm{E}$ are predisposed to an earlier onset for developing $\mathrm{AD}$

\footnotetext{
Received Nov. 5, 2001; revised Nov. 5, 2001; accepted Nov. 30, 2001.

This work was supported by the Deutsche Forschungsgemeinschaft. We thank the following individuals for providing antibodies and reagents: J. Culvenor, C. Elle, J. Gruenberg, M. Zerial, and J. McLauchlan. We also thank B. De Strooper for the gift of PS mutant fibroblasts, T. Y. Chang for providing mutant CHO cell lines, and D. Stephens and G. W. Rebeck for critically reading this manuscript.

Correspondence should be addressed to Tobias Hartmann and Heiko Runz, Center for Molecular Biology (ZMBH), University of Heidelberg, Im Neuenheimer Feld 282, 69120 Heidelberg, Germany. E-mail: tobias.hartmann@mail.zmbh. uni-heidelberg.de or hrunz@ix.urz.uni-heidelberg.de.

Copyright (C) 2002 Society for Neuroscience $\quad 0270-6474 / 02 / 221679-11 \$ 15.00 / 0$
}

(Corder et al., 1993), and a high cholesterol diet accelerates $\mathrm{A} \beta$ deposition in transgenic mice (Refolo et al., 2000). Moreover, suppression of cholesterol neosynthesis strongly reduces the formation of $\mathrm{A} \beta$ species in vivo and in vitro (Simons et al., 1998; Frears et al., 1999; Fassbender et al., 2001; Refolo et al., 2001). Low-density lipoprotein (LDL) receptor family members such as LRP contribute to the endocytosis of APP, suggesting a role for internalization processes in APP metabolism (Kounnas et al., 1995). A fraction of APP molecules, as well as its secretases, localizes to cholesterol-rich membrane subdomains (Bouillot et al., 1996; Riddell et al., 2001). Recent data showing that $\mathrm{A} \beta$ accumulation is associated with NPC1 function (Yamazaki et al., 2001) as well as a strong correlation of cholesterol ester (CE) levels with A $\beta$ generation (Puglielli et al., 2001) indicate that APP processing may be linked to intracellular cholesterol distribution.

In this study we investigate the role of a pathway that mediates the transfer of internalized cholesterol from late endocytic organelles to a sterol-regulating pool in the endoplasmic reticulum (ER) on APP cleavage and PS localization. Mutations in the genes encoding for NPC1 protein or the lysosomal protein HE1 cause cholesterol and other lipids to accumulate in late endosomes and lysosomes, resulting in Niemann-Pick C disease (NPC; Carstea et al., 1997; Naureckiene et al., 2000). Cells mutant in NPC1 show a block in cholesterol esterification by ER resident acyl-coenzyme A:cholesterol acyltransferase (ACAT), suggesting that NPC1 is involved actively in cholesterol transport between late endocytic compartments and the ER (Liscum et al., 1989; Cruz et al., 2000). Class-2 amphiphiles such as U18666A or imipramine mimic NPC disease by inhibiting either NPC1 pro- 
tein itself or an unknown factor along its pathway (Lange et al., 2000).

Here we provide evidence for a link among intracellular cholesterol transport, $\mathrm{A} \beta$ generation, and PS localization. We show that the retention of cholesterol in late endosomal/lysosomal compartments is associated with major alterations in APP processing, inversely affecting $\beta$ - and $\gamma$-secretase cleavage. Surprisingly, this is accompanied by an accumulation of PS1 and PS2 in Rab7-positive vesicular compartments that are directly adjacent to cholesterol-laden late endosomes under conditions in which intracellular cholesterol transport is blocked. Our results indicate that the subcellular distribution of cholesterol is an important factor in regulating the proteolytic cleavage of APP and suggest the possibility of a cholesterol-dependent trafficking of PS.

\section{MATERIALS AND METHODS}

Cell culture. SH-SY5Y cells and mouse fibroblasts were cultivated in DMEM $/ 5 \%$ fetal calf serum (FCS). Mutant Chinese hamster ovary (CHO) cells were grown in Ham-F12/5\% FCS. Rab7-GFP-transfected A431 cells were grown in DMEM/5\% FCS. Rab7 protein was fused at its $\mathrm{N}$ terminus to the $\mathrm{C}$ terminus of GFP with the pEGFP-C3 vector provided by Clontech Laboratories (Cambridge, UK). Stable cell lines were selected and maintained in medium containing $0.5 \mathrm{mg} / \mathrm{ml} \mathrm{G} 418$ (Sigma-Aldrich, Munich, Germany). For the time of exposure to 50

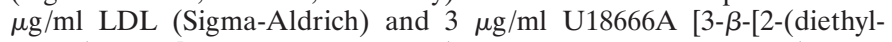
amino)ethoxy]androst-5-en-17-one (Biomol, Hamburg, Germany); from a stock solution in ethanol stored at $-20^{\circ} \mathrm{C}$ for $<3$ months] or $80 \mu \mathrm{M}$ imipramine (Sigma-Aldrich), the FCS levels were increased to $10 \%$ to stimulate cholesterol internalization (Tabas et al., 1988).

Preparation of primary hippocampal neurons from 17-d-old fetal rats was performed as described previously (Goslin and Banker, 1991). Neurons were plated on poly-L-lysine-coated plastic dishes (Nunc, Dannstadt, Germany) or on poly-L-lysine-coated glass coverslips and cultivated under serum-free conditions in MEM containing N2 and B27 supplements (Invitrogen, San Diego, CA). E14 mixed cortical neurons were prepared and cultivated by following the same protocol, with cerebral cortices used instead of hippocampi. Hippocampal neurons were maintained in culture for 12-15 d; cortical neurons were used after 7-10 d in culture.

Antibodies and fluorescent dyes. The following primary antibodies have been described previously: polyclonal anti-PS1 N-terminal fragment (NTF) antibody 95.23 (Culvenor et al., 1997), monoclonal anti-v-ATPase antibody Osw2 (Papini et al., 1996), monoclonal 6C4-antibody to lysobisphosphatidic acid (LBPA; Kobayashi et al., 1998), monoclonal antiCOP-I antibody CM1A10 (Scales et al., 1997), and monoclonal antibody W02 directed to residues 4-10 of human A $\beta$ (Jensen et al., 2000). G2-10 and $\mathrm{G} 2-11$ are monoclonal antibodies specific for the $\mathrm{C}$-terminal residues of $A \beta 40$ and $A \beta 42$, respectively (Ida et al., 1996). Polyclonal antibody 29414 against PS1 CTF was provided by C. Elle (Center for Molecular Biology, University of Heidelberg, Germany). Oil red O (Sigma-Aldrich) was a gift from J. McLauchlan (MRC Virology Unit, University of Glasgow, UK). Monoclonal anti-calnexin and monoclonal anti-BiP/ GRP78 antibodies were from Transduction Laboratories (BD Biosciences, Heidelberg, Germany), monoclonal anti-PS1-loop antibody was from Chemicon (Hof heim, Germany), and polyclonal PS2 antibody was from New England Biolabs (Frankfurt, Germany). For the simultaneous detection of cholesterol, primary antibodies were dissolved in $125 \mu \mathrm{g} / \mathrm{ml}$ filipin (Sigma-Aldrich). Mouse anti-rabbit and rabbit anti-mouse IgG (Alexa-488- or Alexa-568-conjugated) secondary antibodies were from Molecular Probes (Leiden, Netherlands). Horseradish peroxidaseconjugated rabbit anti-mouse or goat anti-rabbit secondary antibodies were from Dako A/S (Glostrup, Denmark).

Immunofluorescence, confocal microscopy, and image processing. Fully polarized hippocampal neurons, SH-SY5Y cells, mutant CHO cells, or A431 cells were incubated with $50 \mu \mathrm{g} / \mathrm{ml} \mathrm{LDL}$ in the presence or absence of 0.75 or $3 \mu \mathrm{g} / \mathrm{ml} \mathrm{U18666A}$ for $24 \mathrm{hr}$. Immunofluorescence labeling was performed according to the standard procedures; cells grown on glass coverslips were fixed in $3 \%$ paraformaldehyde for $10 \mathrm{~min}$ at $4^{\circ} \mathrm{C}$ and permeabilized with either $0.03 \%$ saponin $\left(4^{\circ} \mathrm{C}\right.$ for $\left.1 \mathrm{~min}\right)$ or a brief dip into ice-cold methanol $\left(-20^{\circ} \mathrm{C}\right)$. Alternatively, fixation and permeabilization were performed in ice-cold acetone $\left(-20^{\circ} \mathrm{C}\right.$ for $\left.30 \mathrm{sec}\right)$. Primary antibodies were centrifuged to exclude nonspecific aggregation, and the cells were incubated for $30 \mathrm{~min}$ at $4^{\circ} \mathrm{C}$. After incubation with Alexa- conjugated secondary antibodies the cells were mounted in Mowiol (Calbiochem-Novabiochem, Bad Soden, Germany).

Samples were viewed with a Zeiss LSM 510 confocal microscope (Carl Zeiss, Oberkochen, Germany). Images were acquired with a $63 \times$ or $100 \times$ Plan-Apochromat III differential interference contrast objective (Carl Zeiss). Pinhole settings were $\sim 1$ airy unit for all images except for the detection of filipin (2-3 airy units). Fluorescent dyes were imaged sequentially in frame interlace mode to eliminate cross-talk between the channels. Images were sampled accordingly to satisfy the Nyquist criteria for all dimensions and were processed further with Adobe Photoshop (Mountainview, CA).

Lipid extraction and analysis. Fresh human LDL was mixed with $4\left[{ }^{14} \mathrm{C}\right]$ cholesterol (Amersham Pharmacia Biotech, Braunschweig, Germany) in ethanol (final concentration $<0.1 \%$ ) and dissolved in labeling medium to a final concentration of $50 \mu \mathrm{g} / \mathrm{ml}$ and a total ${ }^{14} \mathrm{C}$ activity of $0.5 \mu \mathrm{Ci} / \mathrm{ml}$. Cells exposed to U18666A or imipramine and the controls were incubated for $2-24 \mathrm{hr}$ at $37^{\circ} \mathrm{C}, 5 \% \mathrm{CO}_{2}$. With the removal of the medium the cells were washed twice with PBS, and the lipids were extracted with hexane/isopropanol (3:2) for $30 \mathrm{~min}$ at $4^{\circ} \mathrm{C}$. Solvent was evaporated under a gentle $\mathrm{N}_{2}$ stream; dried lipids were resolved in a small aliquot of hexane/isopropanol and subjected to unidimensional thin-layer chromatography (TLC) on general purpose silica gel plates (SigmaAldrich) in toluene/ethylacetate (2:1). Quantitative analysis of cholesterol ester formation and internalization of ${ }^{14} \mathrm{C}$-cholesterol were performed after film exposure of TLC plates and densitometric scanning with MacBAS 2 software. For neuronal cells, equal protein levels were checked by the extraction of proteins from cellular debris with $1 \mathrm{~N} \mathrm{NaOH}$ for $10 \mathrm{~min}$ at room temperature, followed by quantification with Coomassie blue protein assay (Pierce, Bezons, France).

Virus infection, immunoprecipitation, and quantitative Western blotting. Recombinant Semliki Forest virus (SFV) encoding human APP695 was prepared and applied as described previously (Tienari et al., 1996). After $8 \mathrm{hr}$ of exposure to $50 \mu \mathrm{g} / \mathrm{ml} \mathrm{LDL}$ and U18666A or ethanol as a solvent control (final concentration, $<0.1 \%$ ), conditioned media were collected and total cellular extracts were prepared with lysis buffer consisting of $1 \%$ NP-40, $1 \%$ Triton X-100, 0.2\% SDS, and 5 mM EDTA supplemented with Complete protease inhibitor cocktail (Roche, Mannheim, Germany). SH-SY5Y cells overexpressing SP-C99 (Dyrks et al., 1993) were incubated with LDL and $3 \mu \mathrm{g} / \mathrm{ml}$ U18666A for $24 \mathrm{hr}$ and processed for immunoprecipitation by a similar protocol. Samples were immunoprecipitated with monoclonal antibodies W02 $(1 \mu \mathrm{g} / \mathrm{ml}), \mathrm{G} 2-10(2 \mu \mathrm{g} / \mathrm{ml})$, or G2-11 $(4 \mu \mathrm{g} / \mathrm{ml})$. For the determination of $\mathrm{A} \beta$ species, Western blot detection of immunoprecipitates was performed according to Ida et al. (1996). Standard A $\beta$ solutions at different concentrations were used for calibration. Western blotting from neuronal lysates was performed with anti-PS1 antibody 95.23 (diluted 1:10,000 in PBS) or monoclonal anticalnexin antibody (diluted 1:1000 in PBS).

\section{RESULTS}

\section{Inhibition of cholesterol trafficking in neuronal cells expressing full-length APP decreases proteolytic processing by $\beta$-secretase}

To elucidate the cellular mechanisms that connect cholesterol and $\mathrm{A} \beta$ generation, we investigated how alterations in intracellular cholesterol distribution might affect APP processing. In peripheral cells the transport of LDL-derived cholesterol to the ER can be inhibited by class-2 amphiphiles (Lange et al., 2000). Because cholesterol homeostasis in brain differs from peripheral tissue (Lütjohann et al., 1996), we first analyzed the transport of internalized cholesterol in neuronal cells by measuring its esterification by ER resident ACAT (Pentchev et al., 1987). SH-SY5Y neuroblastoma cells or fully polarized rat cortical neurons were incubated with LDL enriched in ${ }^{14} \mathrm{C}$-cholesterol in the presence or absence of U18666A or imipramine, and ${ }^{14} \mathrm{C}$-cholesterol ester formation was quantified. SH-SY5Y cells showed a reduction in cholesterol esterification by $>80 \%$ with U18666A treatment and by $>40 \%$ with exposure to imipramine at all time points that were investigated (Fig. 1A). Cholesterol ester levels in primary neurons decreased by $\sim 60 \%$ (39.1\% of control; $n=3 ; p<0.05$ ) (Fig. $1 B)$ with exposure to U18666A. In contrast, cellular ${ }^{14} \mathrm{C}$ - 

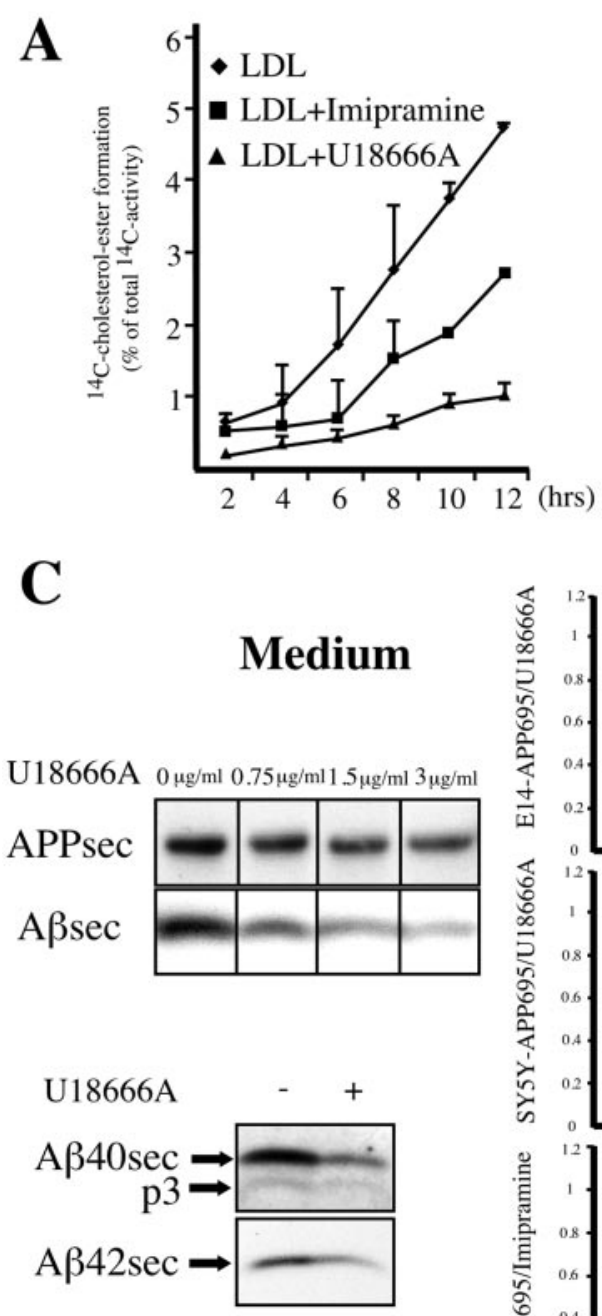

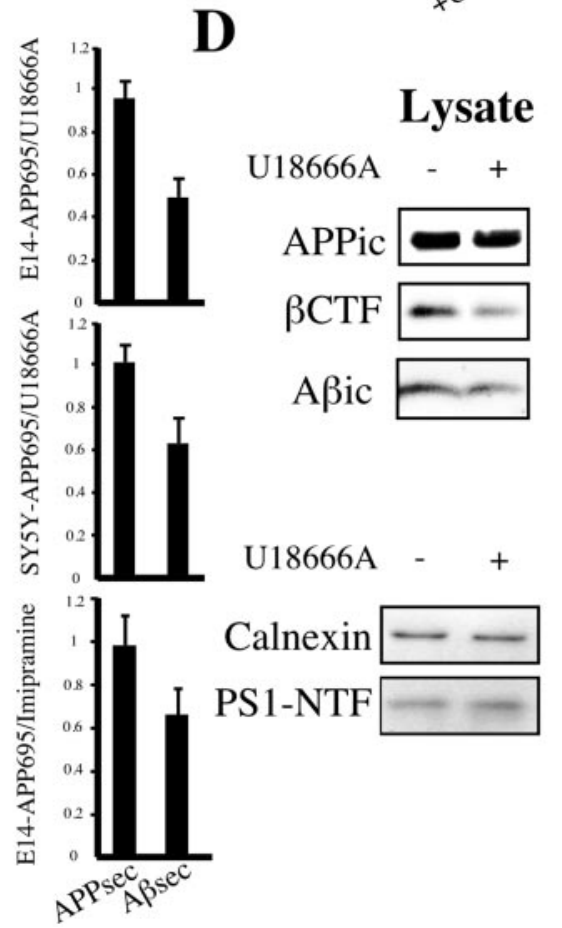

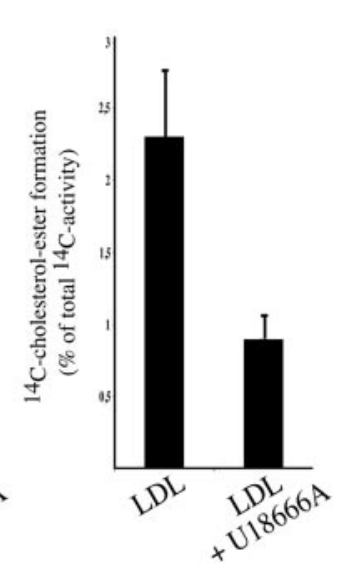

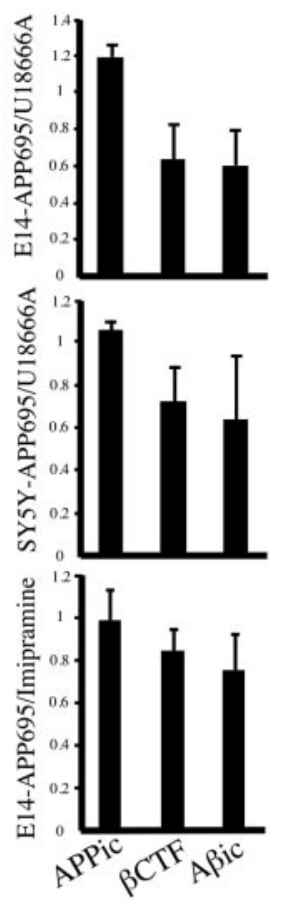

Figure 1. Class 2 amphiphiles inhibit intracellular cholesterol transport and decrease $\beta$-cleavage of APP in neuronal cells. SH-SY5Y cells $(A)$ or mature rat cortical neurons in culture $(B)$ were labeled with ${ }^{14} \mathrm{C}$-cholesterol in LDL for $2-12 \mathrm{hr}(A)$ or $24 \mathrm{hr}(B)$. ${ }^{14} \mathrm{C}$-cholesterol ester formation in cells incubated in the presence or absence of $3 \mu \mathrm{g} / \mathrm{ml}$ (for neuroblastoma cells) or $0.75 \mu \mathrm{g} / \mathrm{ml}$ (for primary neurons) U18666A or $80 \mu \mathrm{M}$ imipramine was monitored by the extraction of lipids and subsequent TLC. Depicted are densitometric quantifications of ${ }^{14} \mathrm{C}$-cholesterol ester signal intensities as a percentage of the total ${ }^{14} \mathrm{C}$ activity per lane (means from three experiments). $C E$, Cholesterol ester; $C$ hol, cholesterol. $C$, SFV-infected mature rat cortical neurons were incubated for $8 \mathrm{hr}$ with LDL at different concentrations of U18666A. Conditioned medium was immunoprecipitated with W02, followed by Western blot detection with W02. Immunoprecipitations of conditioned media from neurons exposed to LDL and either $0.75 \mu \mathrm{g} / \mathrm{ml} \mathrm{U} 18666 \mathrm{~A}(+)$ or not (-) with antibodies G2-10 or G2-11 were detected with G2-10 to visualize secretory A $\beta 40$ and p3 or with W02 for the detection of secretory A $\beta 42$, respectively. $D$, Western blot of respective neuronal lysates with W02 (after W02 immunoprecipitation), anti-calnexin antibody, or antibody 95.23 against PS1 NTF. $C$, $D$, Quantifications of intracellular (ic) and secreted (sec) APP, $\beta$ CTF, and overall A $\beta$ levels $(n=4-7$ experiments). Depicted are ratios of signal intensities from U18666A- or imipramine-treated versus untreated primary cortical neurons or SH-SY5Y cells. Error bars indicate 1 SD.

cholesterol load was not changed significantly, showing that the diminished esterification did not result from a disruption of cholesterol internalization. These results clearly show that cholesterol ester generation from internalized cholesterol takes place in cultured neurons and that these cells, as known from other cell types, show a marked inhibition of cholesterol transfer to metabolizing compartments in response to amphiphiles.

We then investigated the effect of amphiphile-induced inhibition of cholesterol transport on APP processing in neuronal cells. Primary cultures of mixed cortical neurons were infected with recombinant SFV encoding for full-length human APP695. This expression system has been used widely to study sorting and processing of APP in neuronal cells and did not affect neuronal viability within the duration of our experiments (Tienari et al., 1996; De Strooper et al., 1998; Skovronsky et al., 1998). Infected neurons were exposed for $8 \mathrm{hr}$ to LDL in the presence or absence of U18666A. As shown in Figure 1C, the application of U18666A to cortical neurons in culture resulted in a dose-dependent reduction in $\mathrm{A} \beta$ secretion. In contrast, the secretion of APP was reduced only slightly, arguing that diminished $\mathrm{A} \beta$ levels in the medium did not result from a general disruption of protein secretion. At concentrations of $0.75 \mu \mathrm{g}$ of U18666A per milliliter of culture medium the levels of secretory $\mathrm{A} \beta$ decreased by $\sim 50 \%$, whereas APP levels remained essentially unaffected $[0.491 \pm$ 
0.094, $n=4, p<0.01$ for secreted A $\beta$ (A $\beta$ sec); $0.958 \pm 0.08$ for secretory APP (APPsec)]. These observations were independent of the expression system or inhibiting drug, because similar effects could be obtained for SH-SY5Y cells stably expressing APP695 $(0.633 \pm 0.116, n=5, p<0.01$ for $\mathrm{A} \beta \mathrm{sec} ; 1.009 \pm 0.085$ for APPic) as well as exposure of primary neurons to imipramine $(0.661 \pm 0.124, n=7, p<0.001$ for $\mathrm{A} \beta \mathrm{sec} ; 0.98 \pm 0.139$ for APPic). A diminished secretion was prominent for both $\mathrm{A} \beta 40$ and $A \beta 42$, indicating that none of the major $\gamma$-secretase activities was perturbed in favor of the other. Reduced secretion of $\mathrm{A} \beta$ could not be explained by an increase in the $\alpha$-secretory cleavage pathway of APP (Kojro et al., 2001), because we did not observe a compensatory upregulation of p3 levels.

Regardless of the treatment, levels of intracellular APP, calnexin, or PS1 fragments in neuronal lysates were unperturbed (Fig. $1 D$ ). However, we found remarkably less $\beta C$ TF with exposure to U18666A. Quantification revealed a decrease in $\beta$ CTF levels to an extent almost similar to intracellular $\mathrm{A} \beta$ levels in rat primary neurons $[0.524 \pm 0.203, n=4, p<0.05$ for $\beta \mathrm{CTF}$; $0.486 \pm 0.195$ for intracellular $\mathrm{A} \beta$ (A $\beta \mathrm{ic}) ; 0.96 \pm 0.244$ for intracellular APP (APPic)] and human SH-SY5Y cells exposed to $\mathrm{U} 18666 \mathrm{~A}(0.723 \pm 0.163, n=3, p<0.05$ for $\beta \mathrm{CTF} ; 0.64 \pm 0.304$ for A $\beta$ ic; $1.052 \pm 0.053$ for APPic). This effect was not specific for U18666A but also could be found in primary neurons exposed to imipramine $(0.848 \pm 0.1, n=7, p<0.01$ for $\beta \mathrm{CTF} ; 0.755 \pm 0.169$ for A $\beta$ ic; $0.991 \pm 0.148$ for APPic). Taken together, these results show that $\mathrm{A} \beta$ secretion and generation are reduced in neuronal cells inhibited in intracellular cholesterol transport. The similar decrease in $\mathrm{A} \beta$ and $\beta \mathrm{CTF}$ levels indicates that this effect is attributable to a reduction in $\beta$ - rather than $\gamma$-cleavage of fulllength APP.

\section{Inhibition of cholesterol transport increases $\gamma$-secretase cleavage in neuronal cells expressing APP C-terminal fragment SP-C99}

We now were interested in the specific effects that retention of cholesterol in late endosomal/lysosomal compartments might have on $\gamma$-secretase activity. Cleavage by $\gamma$-secretase depends on the previous production of APP $\beta \mathrm{CTF}$, which is generated by $\beta$-secretase. Therefore, the inhibition of $\beta$-secretase may conceal effects on $\gamma$-secretase activity. The use of a truncated form of APP, SP-C99, instead of the full-length molecule, which acts as an immediate precursor for $\mathrm{A} \beta$ and as a direct substrate for $\gamma$-secretase, allows for an isolated assessment of $\gamma$-secretase activity and obviates $\beta$-secretase cleavage for $\mathrm{A} \beta$ generation (Dyrks et al., 1993). $\beta$ CTF-like constructs have been shown previously as suitable models for studying $\gamma$-cleavage in the absence of $\beta$-cleavage (Xia et al., 2000).

We stably transfected SH-SY5Y cells with SP-C99 and exposed these cells to LDL-enriched culture medium in the presence or absence of $3 \mu \mathrm{g} / \mathrm{ml}$ U18666A. Western blot detection showed that levels of endogenously synthesized secretory human APP (APPsec) in conditioned medium from U18666A-treated cells primarily were unaffected compared with controls. Surprisingly, however, secretory and intracellular $\mathrm{A} \beta$ levels were elevated markedly $(1.56 \pm 0.221, n=5, p<0.01$ for A $\beta$ sec; $1.715 \pm 0.172$, $n=5, p<0.0005$ for $\mathrm{A} \beta$ ic) (Fig. $2 A, B)$ ). In contrast, no major changes were found for secretory or intracellular endogenous APP (1.155 \pm 0.134 for APPsec; $0.969 \pm 0.074$ for APPic). Similarly, treatment did not induce differences in C99 levels, the substrate for $\gamma$-secretase after cotranslational cleavage of the signal peptide from SP-C99 (1.059 \pm 0.118 for C99). These results

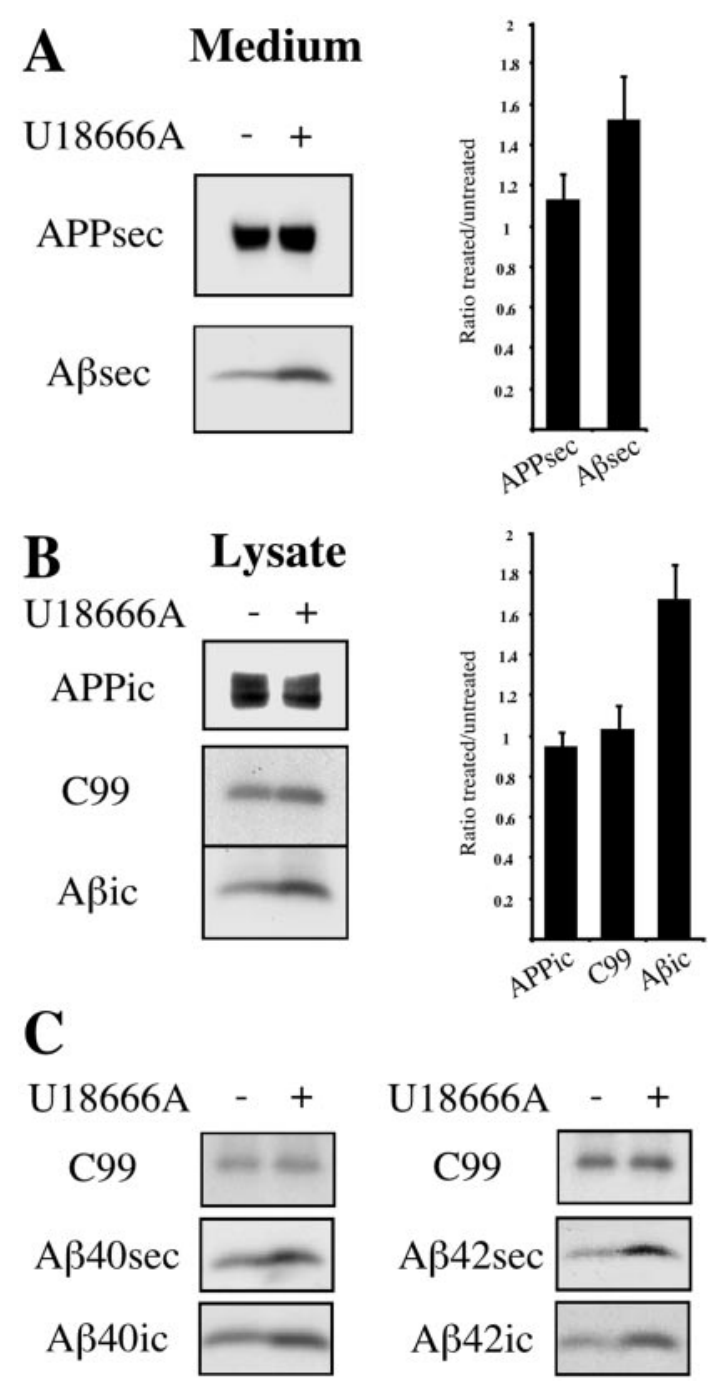

Figure 2. U18666A increases intracellular and secretory $\mathrm{A} \beta$ levels in SP-C99-transfected SH-SY5Y cells. Human SH-SY5Y neuroblastoma cells stably transfected with APP C-terminal fragment SP-C99 were incubated for $24 \mathrm{hr}$ with $50 \mu \mathrm{g} / \mathrm{ml} \mathrm{LDL}$ in the presence $(+)$ or absence $(-)$ of $3 \mu \mathrm{g} / \mathrm{ml} \mathrm{U18666A}$. Conditioned medium $(A)$ and cell lysates $(B)$ were immunoprecipitated with antibody W02, followed by Western blot detection with W02. Graphs show quantification of intracellular (ic) and secreted (sec) endogenous APP, C99, and overall $\mathrm{A} \beta$ levels $(n=5$ experiments). Depicted are ratios of signal intensities from U18666Atreated versus untreated cells. Error bars indicate 1 SD. $C$, Medium and lysates of SH-SY5Y cells were immunoprecipitated with antibodies G2-10 and $\mathrm{G} 2-11$ specific for $A \beta 40$ and $A \beta 42$, respectively, and were detected with W02. Western blots with W02 show effects of U18666A treatment on secretory and intracellular $A \beta$ species compared with C99.

indicate a highly significant increase of $\mathrm{A} \beta$ in neuroblastoma cells exposed to U18666A, indicating a strong upregulation of $\gamma$-secretase activity in response to an altered subcellular cholesterol distribution.

Because of this strong enlargement of overall intracellular and secreted $\mathrm{A} \beta$ pools, we were interested in which of the major $\mathrm{A} \beta$ species might contribute to this effect. We found a remarkable increase in both $\mathrm{A} \beta 40$ and $\mathrm{A} \beta 42$ in cells exposed to U18666A compared with controls (Fig. $2 C$ ). This increase was prominent for secretory as well as for intracellular forms of both $\mathrm{A} \beta$ species, whereas no significant change could be found in the $\mathrm{A} \beta 40 / \mathrm{A} \beta 42$ ratio. 


\section{Inhibition of cholesterol trafficking leads to an accumulation of presenilin1 in vesicular organelles associated with late endosomal/lysosomal compartments}

Given this strong increase in the $\gamma$-secretase product $\mathrm{A} \beta$ with the inhibition of intracellular cholesterol transport, we were interested in whether this effect might correlate with changes in proteins involved in $\gamma$-secretase cleavage. In view of the role for PS in APP processing, we speculated that a stimulation of $\gamma$-cleavage might correlate with an altered subcellular distribution of PS1 (De Strooper and Annaert, 2001). PS1 has been localized to a number of different subcellular compartments, depending on cell type and methods used for its detection. In neuronal cells the majority of PS1 was proposed to reside in the ER and the ER-Golgi intermediate compartment (Annaert et al., 1999). To investigate whether PS1 is affected by alterations in intracellular cholesterol distribution, we exposed SH-SY5Y neuroblastoma cells to U18666A, and we determined PS1 distribution by indirect immunofluorescence and confocal microscopy.

As expected for neuroblastoma cells (Kovacs et al., 1996; Culvenor et al., 1997) and regardless of the presence of LDL, PS1 in untreated and LDL-exposed cells showed a concentration in perinuclear and membranous organelles, although minor signals also were found at the plasma membrane and in vesicular compartments (Fig. 3A). Human vacuolar ATPase as a marker for late endosomes and lysosomes was spread in small vesicular structures throughout the cytosol (Fig. 3B), showing no major colocalization with filipin (Fig. 3C,D), which allows for visualization of cellular cholesterol (Neufeld et al., 1999). However, when cholesterol transport was inhibited by U18666A, v-ATPase-positive vesicles were enlarged and now retained the major pool of cellular cholesterol (Fig. $3 F, G$ ). Surprisingly, under these conditions a large fraction of PS1 signal could be seen in vesicular structures that showed a remarkable overlap with enlarged v-ATPase and filipinpositive vesicles (Fig. $3 E-H$ ). This vesicular staining pattern for PS1 in U18666A-treated SH-SY5Y cells was independent of the antibody that was used. Results were identical with a polyclonal antibody directed to the cytosolic loop region of PS1 CTF, and preimmunoabsorption of antibody 95.23 with PS1 NTF1-20 synthetic peptide abolished signals in both treated and untreated cells (data not shown).

U18666A has been used widely to mimic a cholesteroltrafficking defect naturally occurring in Niemann-Pick C disease (Lange et al., 2000). As an alternative cellular model for NPC we used a mutant CHO cell line, CHO-CT43 (Cruz et al., 2000), which expresses a nonfunctional C-terminally truncated NPC1 protein and determined PS1 localization. After $24 \mathrm{hr}$ of incubation in culture medium containing FCS and LDL, mutant $\mathrm{CHO}$ cells were fixed and stained for PS1 and cholesterol. As a late endosomal marker the monoclonal antibody 6C4 was used, which recognizes LBPA, a phospholipid highly enriched in internal membranes of late endosomes (Kobayashi et al., 1998). Like in U18666A-treated SH-SY5Y cells, PS1 frequently was associated with LBPA- and cholesterol-rich compartments in CHO-CT43 cells (Fig. 3M-P). In contrast, a predominantly ER-like staining pattern for PS1 was found in parental CHO-25R A cells, in which transport of internalized cholesterol to cholesterol-metabolizing compartments is active (Cruz et al., 2000) (Fig. 3I-L). These results from cholesterol-trafficking mutant stable cell lines show that effects of impaired cholesterol trafficking on PS1 localization are not attributable to potential short-term disturbances in mem- brane lipid composition by U18666A and suggest a correlation of cholesterol retention in late endosomal/lysosomal compartments and PS1 compartmentalization.

A more detailed analysis of U18666A-induced PS1-containing structures in SH-SY5Y cells revealed that PS1-containing compartments did not overlap completely with v-ATPase and presumably cholesterol-filled compartments but frequently appeared to surround these in a ring-like manner (Fig. 4A-C). Organelles positive for NPC1 and Rab7 with a very similar morphology and involved in cholesterol sorting have been described in fibroblasts enriched in LDL-derived cholesterol (Neufeld et al., 1999; Z hang et al., 2001). We therefore made use of a human A431 cell line stably expressing Rab7-GFP (M. de Bernard, unpublished data) and performed coimmunolabeling with a monoclonal antibody directed to the cytosolic loop region of PS1 CTF. As shown in Figure $4 D-F$, U18666A-treated cells showed a prominent colocalization of Rab7 and PS1 in vesicular structures that were concentrated in perinuclear areas. Colocalization with polyclonal antibody against PS2 showed that under these conditions PS2 also localized to these compartments (Fig. 4G-I). However, these compartments were not identical with lipid storage droplets (Pol et al., 2001) visualized with the neutral lipid stain Oil red O (Fig. $4 J-L)$. Instead, with a localization near to the nucleus and a ring-like morphology surrounding a central cavity reported previously (Neufeld et al., 1999; Zhang et al., 2001), our findings argue strongly for an accumulation of PS in vesicular compartments involved in intracellular cholesterol distribution.

\section{PS1 and $A \beta 42$ colocalize in Rab7-positive vesicular compartments in primary hippocampal neurons}

We next analyzed the effects of U18666A on primary hippocampal neurons in culture. Colabeling of the late endosomal marker LBPA and filipin at higher magnification showed a notable overlap (Fig. 5C,E), confirming LBPA-positive late endosomes as cholesterol-retaining organelles after treatment of the cells with amphiphiles (Zhang et al., 2001). In contrast, Rab7-positive organelles were associated spatially with, but clearly distinct from, late endosomes enriched in cholesterol (Fig. 5F,H). Aggregated $\mathrm{A} \beta$ had been described previously in Rab7-positive endosomal fractions in U18666A-treated peripheral cells (Yamazaki et al., 2001). Thus we tested whether PS1 and A $\beta$ colocalized to the same vesicular compartments in hippocampal neurons. As shown in Figure $5 G$ and like in peripheral cells, PS1 in U18666A-treated hippocampal neurons distributed to vesicular compartments most likely corresponding to Rab7-positive organelles. Under these conditions in a subset of neurons the predominant fraction of endogenous $\mathrm{A} \beta 42$ localized to PS1-containing vesicular compartments (Fig. $5 G-I$ ), indicating a close relationship of cholesterol retention, PS1 distribution, and increased $\gamma$-secretase activity.

To determine the specificity of PS1 accumulation with the exposure of neurons to U18666A, we performed coimmunolocalization with markers for different subcellular compartments. $\beta^{\prime}-\mathrm{COP}$ as a component of COP-I coats and parental Golgi membranes was largely excluded from PS1 or cholesterol-containing organelles (Fig. 6A-D). Similarly, no spatial correlation to filipin-positive compartments could be found for ER resident BiP/GRP78 (Fig. $6 E-H)$, suggesting that an accumulation in vesicular compartments is not a general response of ER proteins after preventing delivery of cholesterol to the ER. Surprisingly, however, when we investigated the localization of ER protein calnexin in response to 

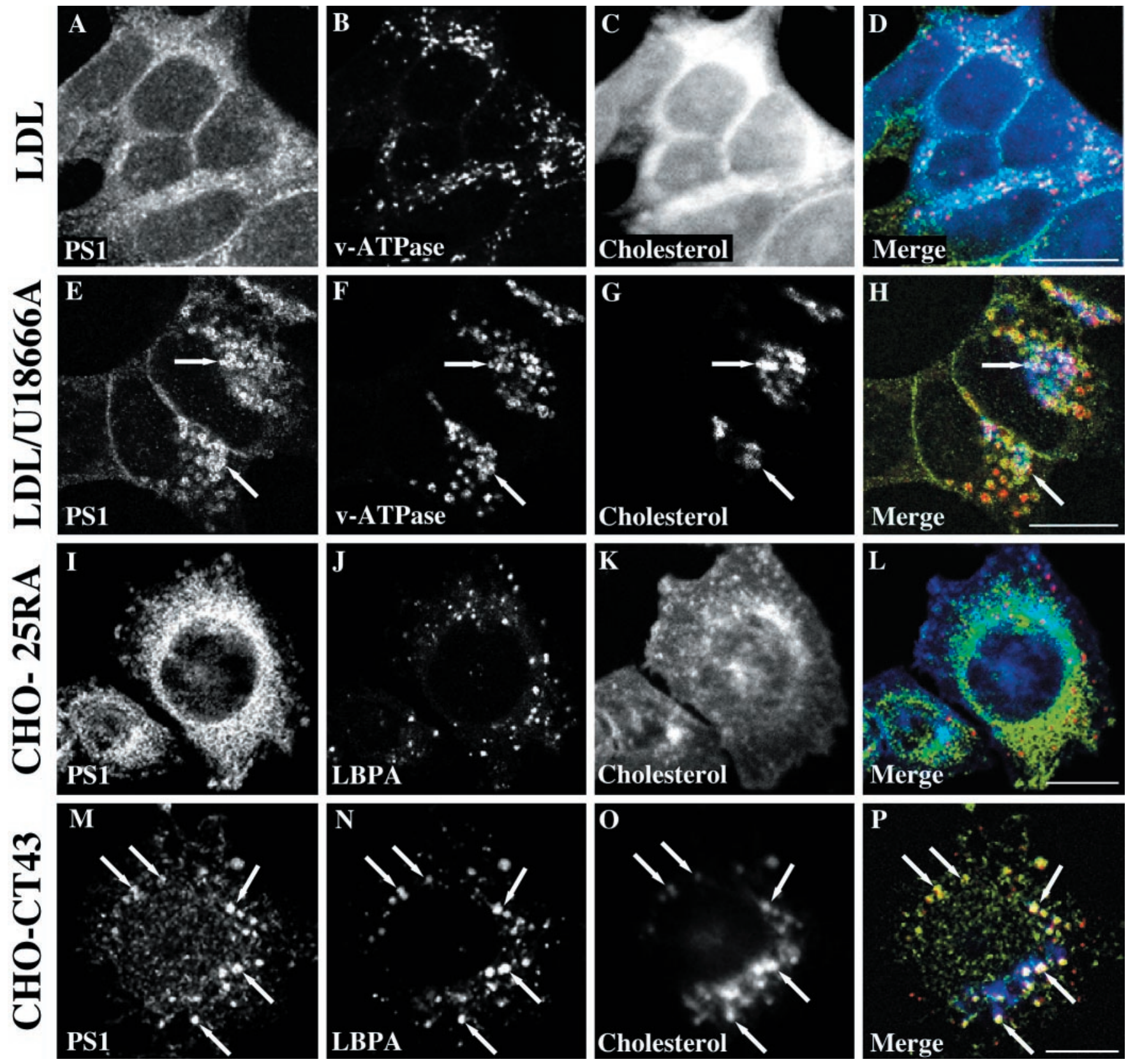

Figure 3. Inhibiting intracellular cholesterol transport induces an accumulation of PS1 in vesicular compartments associated with late endosomes and lysosomes. Human SH-SY5Y neuroblastoma cells were incubated for $24 \mathrm{hr}$ with $50 \mu \mathrm{g} / \mathrm{ml} \mathrm{LDL}$ in the presence $(E-H)$ or absence $(A-D)$ of $3 \mu \mathrm{g} / \mathrm{ml}$ U18666A. After fixation in paraformaldehyde the cells were triple labeled with polyclonal PS1 antibody 95.23 ( $A$, E; green fluorescence), monoclonal antibody Osw2 to v-ATPase as a late endosomal/lysosomal marker ( $B, F$; red fluorescence), and filipin for the detection of cellular cholesterol ( $C$, $G$; blue fluorescence). Parental CHO-25RA cells (with regular sterol distribution) and CHO-CT43 cells (expressing a nonfunctional NPC1 protein) were incubated with $50 \mu \mathrm{g} / \mathrm{ml} \mathrm{LDL}$ for $24 \mathrm{hr}$, fixed with paraformaldehyde, and triple labeled with PS1 antibody 95.23 (I, $M)$, filipin $(K, O)$, and the monoclonal antibody $6 \mathrm{C} 4$ against LBPA to visualize late endosomes ( $J, N$; red fluorescence). $D, H, L, P$, Merged images. Arrows indicate selected regions positive for all three markers. Scale bars, $10 \mu \mathrm{m}$.

U18666A (Fig. 6J), a fraction of calnexin became prominent in punctuate structures associated with PS1-positive and cholesterolretaining compartments (Fig. 4D-F). Higher magnification suggested that calnexin and PS1 partially colocalized to identical vesicular organelles.

Finally, we tested whether the effects of U18666A on cholesterol transport were attributable to potential direct effects on PS. Fibroblasts from PS1 knock-out and PS1/PS2 double knock-out mice (Armogida et al., 2001) were exposed to U18666A, and CE generation in treated and untreated cells was determined. As shown in Figure 7, CE formation from internalized cholesterol can occur regardless of PS1 expression. Furthermore, U18666A decreased CE generation to a similar degree in wild-type and knock-out cells. Correspondingly, retention of cholesterol in late endosomes with the blocking of cholesterol transport by U18666A was unchanged (data not shown). Together, these results suggest that, although PS1 expression is not essential for an efficient transfer of internalized cholesterol to metabolizing sites, PS1 

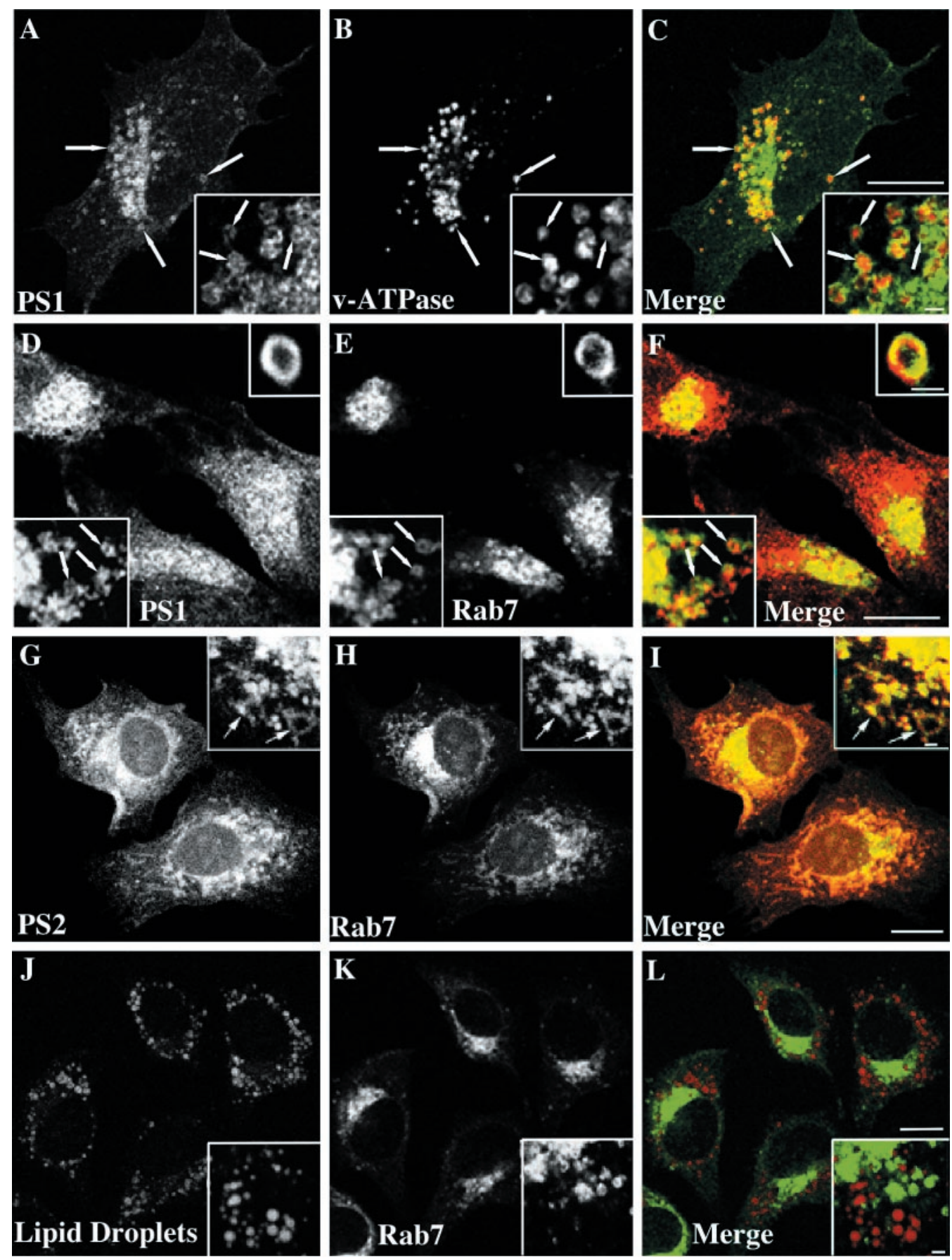

Figure 4. PS-containing compartments are positive for Rab7 and surround late endosomes in a ring-like manner. SH-SY5Y $(A-C)$ or A431 cells $(D-L)$ were incubated for $24 \mathrm{hr}$ with $50 \mu \mathrm{g} / \mathrm{ml} \mathrm{LDL}$ and $3 \mu \mathrm{g} / \mathrm{ml}$ U18666A. After fixation in paraformaldehyde the SH-SY5Y cells were stained against PS1 $(A, C$; green $)$ and v-ATPase $(B, C ;$ red $)$. Fixed A431 cells stably overexpressing Rab7-GFP $(E, H, K$; green $)$ were labeled with a monoclonal PS1 antibody $(D, F ;$ red $)$, polyclonal PS2 antibody $(G, I ;$ red $)$, or Oil red O to visualize neutral lipids $(J, L ; r e d)$. C, F, I, L, Merged images. Scale bars, $8 \mu$ m. Arrows indicate selected vesicles positive for both markers. Insets show single sections from confocal stacks of random vesicular structures in cell bodies. Scale bars in insets, $1 \mu \mathrm{m}$.

localization in hippocampal neurons correlates highly with the intracellular distribution of cholesterol.

\section{DISCUSSION}

This study reports that the intracellular distribution of cholesterol has substantial effects on the subcellular localization of PS and the amyloidogenic processing of APP. Our results suggest that the compartmentalization of cholesterol in neurons may play an important role in how cholesterol alters $\mathrm{A} \beta$ generation. We deter- mined the effects of intracellular cholesterol distribution on PS localization and APP cleavage by two means, first by using compounds that inhibit cholesterol transport from endocytic compartments to the ER and second by examining cells expressing mutant NPC1.

We describe a dose-dependent reduction in both secreted and cellular $A \beta$ species in neurons and neuroblastoma cells exposed to cholesterol transport-inhibiting amphiphiles. For several rea- 

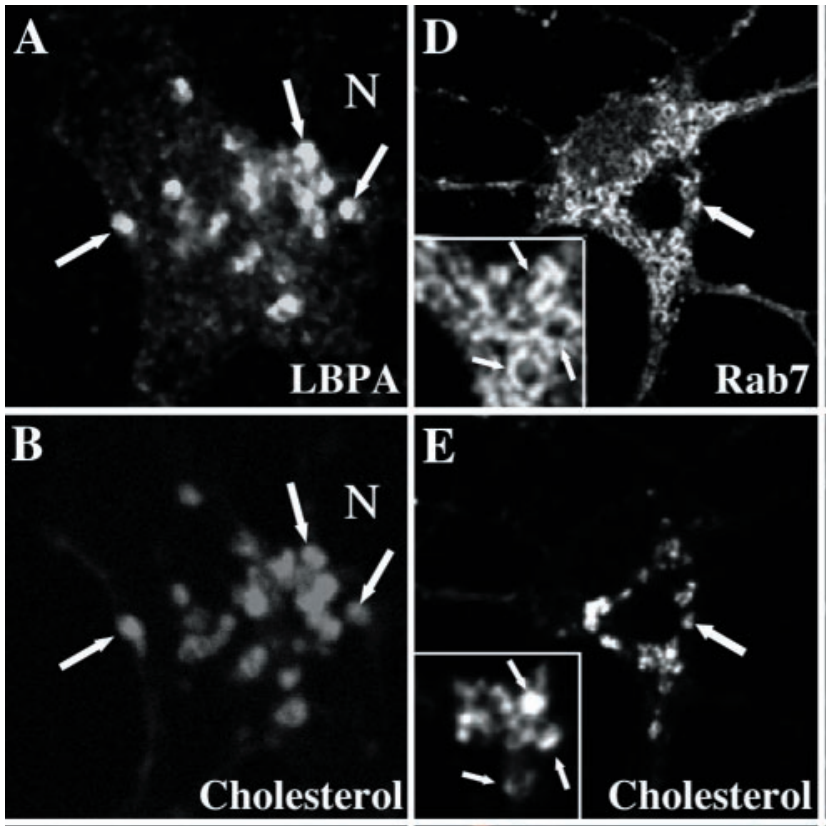

Figure 5. Rab7-containing compartments
after U18666A exposure of hippocampal neurons are distinct from cholesterolretaining late endosomes and retain $\mathrm{A} \beta 42$ and PS1. Mature hippocampal neurons were incubated with LDL and U18666A for $24 \mathrm{hr}$, fixed, and stained with filipin $(B, E$; red $)$ and either monoclonal antibody $6 \mathrm{C} 4$ against LBPA $(A, C$; green $)$ or a polyclonal antibody against $\operatorname{Rab7}(D, F$; green). $G, H$, Coimmunostainings of 95.23 for PS1 and monoclonal antibody $\mathrm{G} 2-11$ to detect cellular A $\beta 42$. $A-C$ and insets in $D-I$ show areas in the cell body of a hippocampal neuron. $C$, Merged image from $A, B . F$, Merged image from $D, E . I$, Merged image from $G, H$. Arrows indicate selected compartments. Scale bars, $4 \mu \mathrm{m}$.
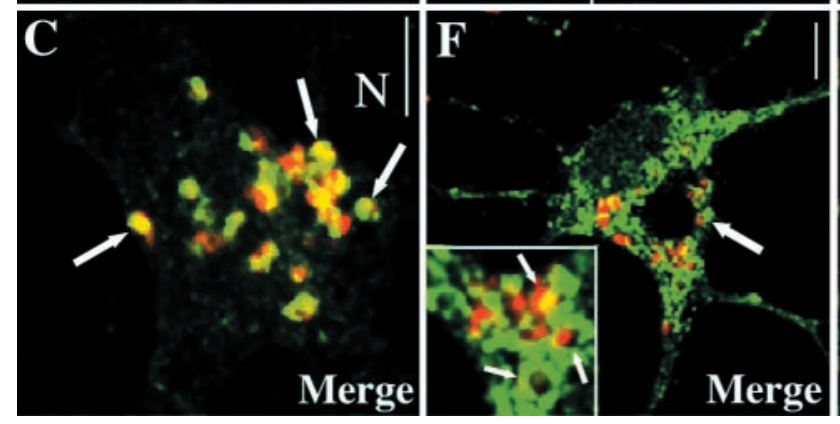

sons we propose that the reduced formation of $\mathrm{A} \beta$ is attributable to a reduced $\beta$-cleavage of APP. First, $\beta$ CTF levels decrease to an almost similar extent as overall secreted and intracellular $\mathrm{A} \beta$, and $\mathrm{A} \beta 40$ and $\mathrm{A} \beta 42$ both decrease to a similar degree. Second, levels in APPsec and p3 do not rise, indicating that $\alpha$-secretase cleavage of APP was not increased. Our results confirm previous data showing a strong correlation of $\beta$-secretase activity and cholesterol metabolism in neuronal cells (Simons et al., 1998).

There are several possible mechanisms for how changes in subcellular cholesterol distribution could alter the $\beta$-secretase cleavage of APP. We cannot exclude indirect effects on APP processing caused by alterations in endosomal or TGN function (Pentchev et al., 1987) or consecutive regulatory mechanisms after decreased transport of sterols to the ER (DeBose-Boyd et al., 1999). However, intriguing possibilities argue for a more direct role of the intracellular cholesterol transport on $\mathrm{A} \beta$ production. For example, reinternalization of surface APP during $\mathrm{A} \beta$ generation may be affected by a decreased cholesterol content in the plasma membrane in response to cholesterol-depleting agents that also reduce cholesterol transport to the ER (Subtil et al., 1999; H. Runz and T. Hartmann, unpublished results). Because the $\beta$-secretase BACE1 has been shown to localize to lipid rafts (Riddell et al., 2001) and NPC1 plays a role in raft dynamics (Lusa et al., 2001), retention of cholesterol in endosomal/lysosomal compartments might interfere directly with $\beta$-secretase function. Our findings of a reduced $\beta$-cleavage of APP after the inhibition of cholesterol transport to the ER also correspond to a recent study showing a strong correlation of $\mathrm{A} \beta$ production and cellular CE levels (Puglielli et al., 2001). Inhibition of ACAT was associated with a prominent reduction in $\mathrm{A} \beta$ generation, which resulted from an inhibition of all three major processing events of APP.

Unexpectedly and in contrast to what we observed for $\beta$-secretase cleavage, we found a dramatic increase in $\gamma$-secretase activity accompanied by higher levels of secreted and intracellular $\mathrm{A} \beta$ when the transfer of LDL-derived cholesterol from endocytic compartments to ACAT in the ER was inhibited. This increase was prominent in cells expressing the $\beta$ CTF analog SP-C99 but was concealed in cells expressing full-length APP, where an increased $\gamma$-cleavage could not compensate for a reduction in $\beta$-cleavage as the rate-limiting step in $\mathrm{A} \beta$ generation. We cannot rule out that the effects on $\gamma$-secretase are attributable to downstream effects on ACAT itself or mechanisms important for CE formation. However, a direct influence of NPC1 function or the transport of free cholesterol or other lipids to the ER on APP cleavage cannot be excluded.

This is supported further by the fact that regardless of how cholesterol transport was inhibited, we found a prominent accumulation of PS in vesicular organelles positive for Rab7 and intimately associated, but not identical, with cholesterol-retaining late endosomes. During cholesterol transport from the plasma membrane to the ER vesicular compartments are involved that contain NPC1 protein and are associated spatially but that are distinct from endosomal/lysosomal compartments required for the initial uptake of lipoprotein-derived cholesterol (Neufeld et al., 1999). Whereas cholesterol-enriched late endosomes are pos- 

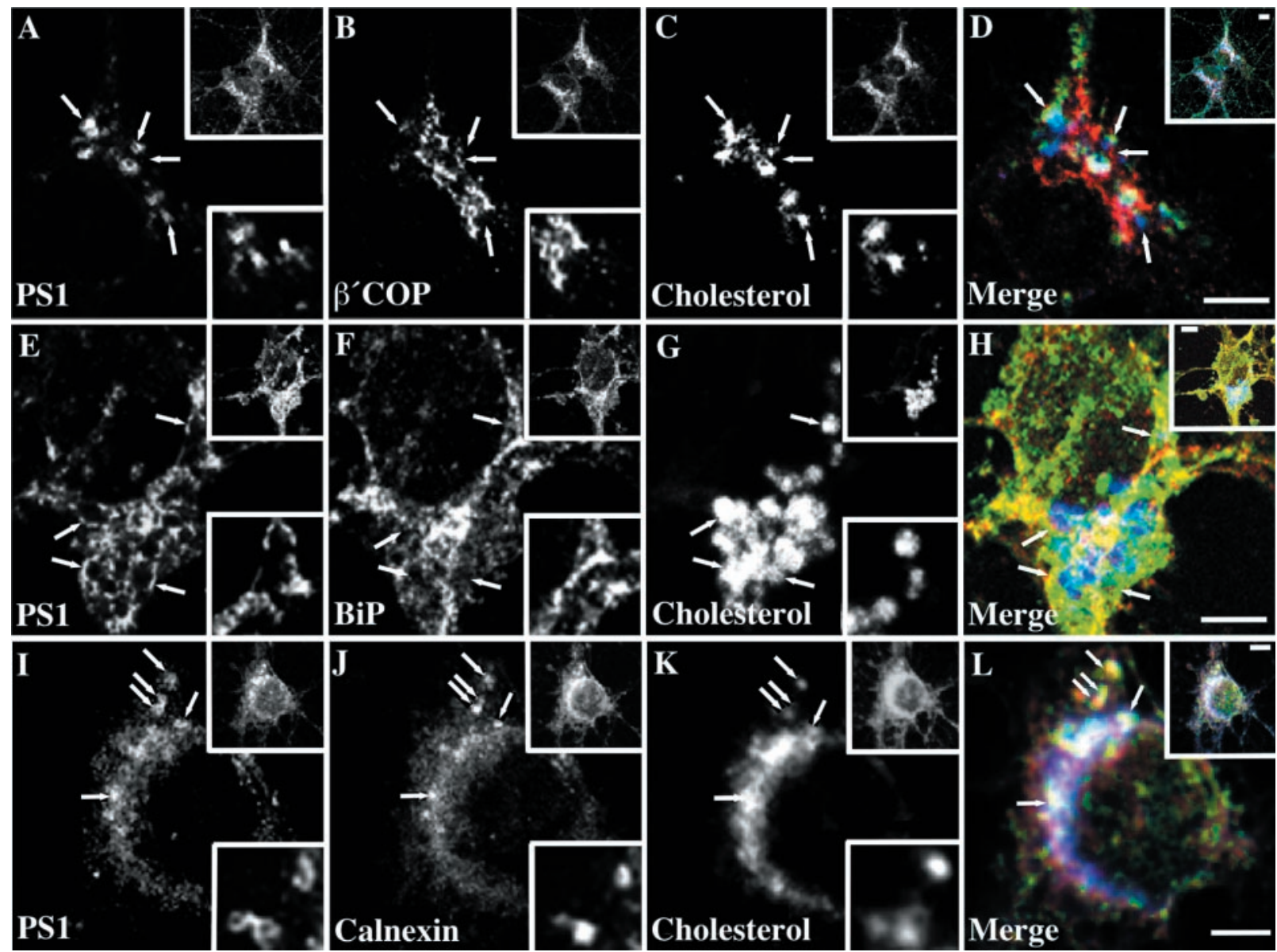

Figure 6. PS1-bearing vesicular compartments in hippocampal neurons impaired in cholesterol transport exclude $\beta^{\prime} \mathrm{COP}$ and BiP but retain calnexin. Fully polarized rat hippocampal neurons in culture were incubated with $50 \mu \mathrm{g} / \mathrm{ml} \mathrm{LDL}$ and $0.75 \mu \mathrm{g} / \mathrm{ml}$ U18666A for 24 hr. Neurons were fixed and triple labeled with antibody $95.23(A, E, I)$, filipin $(C, G, K)$, and monoclonal antibodies against $\beta^{\prime} \mathrm{COP}(B)$, BiP/GRP78 $(F)$, or calnexin $(J)$. $D, H, L$, Merged images. Bottom insets show selected regions of single sections in the cell body of the depicted neuron (top insets). Arrows indicate selected compartments. Scale bars, $3 \mu \mathrm{m}$.

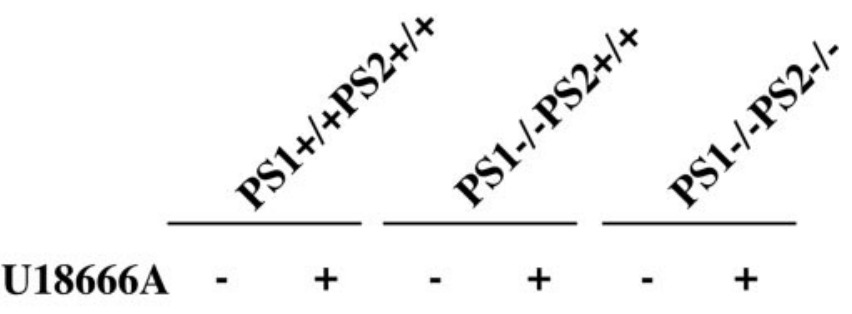

CE

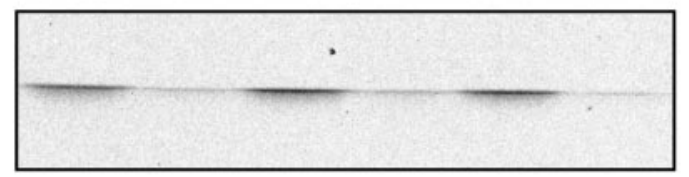

Figure 7. U18666A decreases cholesterol ester formation independently of PS1 expression. Cultured mouse fibroblasts from wild-type (PS1+/ $+\mathrm{PS} 2+/+)$, PS1 single knock-out (PS1-/-PS2+/+), and PS1/PS2 double knock-out (PS1-/-PS2-/-) mice were labeled with ${ }^{14} \mathrm{C}$-cholesterol in LDL in the presence $(+)$ or absence $(-)$ of $3 \mu \mathrm{g} / \mathrm{ml} \mathrm{U18666A}$ for $24 \mathrm{hr}$. Lipids were extracted and separated by TLC. Effects of U18666A on CE formation in treated cells at equal CE levels in untreated cells are shown.

itive for lysosomal hydrolases, LBPA, and endocytic fluorescentlabeled dyes, NPC1-containing structures exclude these markers but are enriched instead in Rab7 and certain glycolipids (Zhang et al., 2001). The NPC1 compartment was described as a mem- branous organelle often surrounding cholesterol-laden late endosomes in a ring-like manner that may have a role in cholesterol sorting and the rapid transport of material between the plasma membrane and the ER (Cruz et al., 2000; Ko et al., 2001). The colocalization of PS with Rab7 as well as an identical morphology of PS-containing structures in our experiments indicate that, on blocking intracellular cholesterol transport, PS accumulates in these vesicular organelles involved in cholesterol sorting.

The localization of PS in vesicular organelles was surprising, because convincing evidence from neuronal cells shows a steadystate localization of PS1 predominantly in the ER (Kovacs et al., 1996; Culvenor et al., 1997; Annaert et al., 1999). Internalization of lipoprotein-derived cholesterol by neurons was reported to be low (Lütjohann et al., 1996). Nevertheless, neurons express LDL receptor family members (Herz et al., 1988), NPC1 (Falk et al., 1999) and ACAT (Sakashita et al., 2000) and thus possess molecular equipment involved in the uptake and utilization of lipoprotein-derived cholesterol. Accordingly, in our experiments amphiphiles diminished esterification of LDL-derived cholesterol in SH-SY5Y cells and primary cortical neurons. The block in cholesterol transfer to ACAT-containing compartments was sufficient to induce a massive accumulation of cholesterol in late endosomes positive for LBPA but distinct from Rab7-containing organelles. These results indicate that the intracellular transport 
of internalized cholesterol in primary neurons essentially follows identical routes as in peripheral cells (Zhang et al., 2001). Correspondingly, PS1 localized to vesicular compartments in the cell bodies of hippocampal neurons. Most interestingly, we also could detect a large fraction of $\mathrm{A} \beta 42$ in these compartments. These microscopic data from neuronal cells inhibited in intracellular cholesterol transport are in accordance with a study showing a significant accumulation of $\mathrm{A} \beta$ in both NPC1 mutant $\mathrm{CHO}$ cells and NPC mouse brain (Yamazaki et al., 2001). In addition to their results proposing a pool of aggregated $\mathrm{A} \beta 42$ in cholesteroland Rab7-containing gradient fractions, our data showing a colocalization of PS1 and $\mathrm{A} \beta 42$ raise the possibility that under these conditions $\mathrm{A} \beta 42$ is produced in vesicular compartments involved in neuronal cholesterol transport.

How might an inhibition of intracellular cholesterol transport induce a shift in PS distribution and an increased $\gamma$-secretase activity? One possibility is that alterations in subcellular cholesterol distribution might induce changes in ER membrane composition that could alter ER stability (Orci et al., 1984) and favor a relocalization of ER proteins to compartments involved in cholesterol sorting. This might be a reason for the unexpected localization of a fraction of ER membrane protein calnexin to these organelles in hippocampal neurons. The accumulation of PS and presumably other factors in Rab7- and NPC1-bearing organelles also might favor the assembly of the active highmolecular-weight $\gamma$-secretase complex, which might stimulate formation of $\mathrm{A} \beta$ in these compartments. Because the site for $\gamma$-cleavage of $\beta$ CTF is within the membrane domain of APP, a unique lipid composition of PS- and NPC1-containing compartments might favor $\mathrm{A} \beta$ generation further.

Alternatively, the redistribution of PS to organelles involved in cholesterol trafficking might support a proposed ER export model for PS-dependent $\gamma$-cleavage of APP (De Strooper and Annaert, 2001). Analogies between APP processing and sterol-dependent trafficking and proteolysis in the regulation of sterol homeostasis are intriguing. When ER membranes are depleted from cholesterol, the sterol response element binding protein (SREBP) cleavage-activating protein (SCAP) escorts SREBP to the Golgi, where Site-1 protease activates SREBP, which subsequently is cleaved by an intramembranous proteolytic event that is very similar to the $\gamma$-cleavage of APP (DeBose-Boyd et al., 1999). Recent data from living cells demonstrate a close interaction of NPC1-bearing organelles and the ER (Ko et al., 2001), and a threshold concentration of cholesterol in the endosomal/lysosomal system was proposed to induce a shift in NPC1 localization from a diffuse membranous organelle to these compartments (Zhang et al., 2001).

In conclusion, our results show that the intracellular compartmentalization of cholesterol is an important factor in determining PS localization and the regulation of APP cleavage. Further experiments in additional cellular and in vivo models systems will be required to elucidate its potential physiological and pathological implications on APP processing. In view of recent clinical studies reporting a potential benefit of regulating cholesterol metabolism as a strategy for preventing the onset of AD symptoms (Jick et al., 2000; Wolozin et al., 2000), our findings may help to design therapeutic approaches to cholesterol-dependent cellular events associated with AD. In providing a plausible link between factors such as ApoE or LRP in the endocytic limb and subsequent cholesterol-regulating events in the ER where, under balanced conditions, the major pool of PS is localized and $\gamma$-cleavage may occur, we propose the intracellular cholesterol transport as a potential crossroad in $\mathrm{A} \beta$ generation.

\section{REFERENCES}

Annaert WG, Levesque L, Craessaerts K, Dierinck I, Snellings G, Westaway D, St. George-Hyslop P, Cordell B, Fraser P, De Strooper B (1999) Presenilin 1 controls $\gamma$-secretase processing of amyloid precursor protein in pre-Golgi compartments of hippocampal neurons. J Cell Biol 147:277-294.

Armogida M, Petit A, Vincent B, Scarzello S, Alves da Costa C, Checler $\mathrm{F}$ (2001) Endogenous $\beta$-amyloid production in presenilin-deficient embryonic mouse fibroblasts. Nat Cell Biol 3:1030-1033.

Bouillot C, Prochiantz A, Rougon G, Allinquant B (1996) Axonal amyloid precursor protein expressed by neurons in vitro is present in a membrane fraction with caveolae-like properties. J Biol Chem 271:7640-7644.

Carstea ED, Morris JA, Coleman KG, Loftus SK, Zhang D, Cummings C, Gu J, Rosenfeld MA, Pavan WJ, Krizman DB, Nagle J, Polymeropoulos MH, Sturley SL, Ioannou YA, Higgins ME, Comly M, Cooney A, Brown A, Kaneski CR, Blanchette-Mackie EJ, et al. (1997) Niemann-Pick C1 disease gene: homology to mediators of cholesterol homeostasis. Science 277:228-231.

Corder EH, Saunders AM, Strittmatter WJ, Schmechel DE, Gaskell PC, Small GW, Roses AD, Haines JL, Periak-Vance MA (1993) Gene dose of apolipoprotein type 4 allele and the risk of Alzheimer's disease in late onset families. Science 261:921-923.

Cruz JC, Sugii S, Yu C, Chang TY (2000) Role of Niemann-Pick type $\mathrm{C} 1$ protein in intracellular trafficking of low density lipoprotein-derived cholesterol. J Biol Chem 275:4013-4021.

Culvenor JG, Maher F, Evin G, Malchiodi-Albedi F, Cappai R, Underwood JR, Davis JB, Karran EH, Roberts GW, Beyreuther K, Masters CL (1997) Alzheimer's disease-associated presenilin 1 in neuronal cells: evidence for localization to the endoplasmic reticulum-Golgi intermediate compartment. J Neurosci Res 49:719-731.

DeBose-Boyd RA, Brown MS, Li WP, Nohturfft A, Goldstein JL, Espenshade PJ (1999) Transport-dependent proteolysis of SREBP: relocation of site-1 protease from Golgi to ER obviates the need for SREBP transport to Golgi. Cell 99:703-712.

De Strooper B, Annaert W (2000) Proteolytic processing and cell biological functions of the amyloid precursor protein. J Cell Sci 113:1857-1870.

De Strooper B, Annaert W (2001) Presenilins and the intramembrane proteolysis of proteins: facts and fiction. Nat Cell Biol 3:E221-E225.

De Strooper B, Saftig P, Craessaerts K, Vanderstichele H, Guhde G, Annaert W, Von Figura K, Van Leuven F (1998) Deficiency of presenilin-1 inhibits the normal cleavage of amyloid precursor protein. Nature 391:387-390.

Dyrks T, Dyrks E, Monning U, Urmoneit B, Turner J, Beyreuther K (1993) Generation of $\beta A 4$ from the amyloid protein precursor and fragments thereof. FEBS Lett 335:89-93.

Falk T, Garver WS, Erickson EP, Wilson JM, Yool AJ (1999) Expression of Niemann-Pick type $C$ transcript in rodent cerebellum in vivo and in vitro. Brain Res 839:49-57.

Fassbender K, Simons M, Bergmann C, Stroick M, Lütjohann D, Keller $\mathrm{P}$, Runz $\mathrm{H}$, Kühl S, Bertsch T, von Bergmann $\mathrm{K}$, Hennerici $M$, Beyreuther K, Hartmann T (2001) Simvastatin strongly reduces levels of Alzheimer's disease $\beta$-amyloid peptides A $\beta 42$ and A $\beta 40$ levels in vitro and in vivo. Proc Natl Acad Sci USA 98:5856-5861.

Frears ER, Stephens DJ, Walters CE, Davies H, Austin BM (1999) The role of cholesterol in the biosynthesis of $\beta$-amyloid. NeuroReport 10:1699-1705.

Goslin K, Banker G (1991) Rat hippocampal neurons in low-density culture. In: Cultivating nerve cells (Banker G, Goslin K, eds), pp 251-281. Cambridge, MA: MIT.

Herz J, Hamann U, Rogne S, Mykelbost O, Gausepohl H, Stanley KK (1988) Surface location and high affinity for calcium of a $500 \mathrm{kD}$ liver membrane protein related to the LDL receptor suggest a physiological role as lipoprotein receptor. EMBO J 7:4119-4127.

Ida N, Hartmann T, Pantel J, Schroeder J, Zerfass R, Foerstel H, Sandbrink R, Masters CL, Beyreuther K (1996) Analysis of heterogeneous $\beta$ A4 peptides in human cerebrospinal fluid and blood by a newly developed sensitive Western blot assay. J Biol Chem 271:22908-22914.

Jensen M, Hartmann T, Engvall B, Wang R, Uljon SN, Sennvik K, Naslund J, Muehlhauser F, Nordstedt C, Beyreuther K, Lannfelt L (2000) Quantification of Alzheimer amyloid $\beta$-peptides ending at residues 40 and 42 by novel ELISA systems. Mol Med 6:291-302.

Jick H, Zornberg GL, Jick SS, Seshadri S, Drachman DA (2000) Statins and the risk of dementia. Lancet 356:1627-1631.

Ko DC, Gordon MD, Jin JY, Scott MP (2001) Dynamic movements of organelles containing Niemann-Pick C1 protein: NPC1 involvement in late endocytic events. Mol Biol Cell 12:601-614.

Kobayashi T, Stang E, Fang KS, De Moerloose P, Parton RG, Gruenberg J (1998) A lipid associated with the anti-phospholipid syndrome regulates endosome structure and function. Nature 392:193-197. 
Kojro E, Gimpl G, Lammich S, März W, Fahrenholz F (2001) Low cholesterol stimulates the nonamyloidogenic pathway by its effect on the $\alpha$-secretase ADAM10. Proc Natl Acad Sci USA 98:5815-5820.

Kounnas MZ, Moir RD, Rebeck GW, Bush AI, Argraves WS, Tanzi RE, Hyman BT, Strickland DK (1995) LDL receptor-related protein, a multifunctional ApoE receptor, binds secreted $\beta$-amyloid precursor protein and mediates its degradation. Cell 82:331-340.

Kovacs DM, Fausett HJ, Page KJ, Kim TW, Moir RD, Merriam DE, Hollister RD, Hallmark OG, Mancini R, Felsenstein KM, Hyman BT, Tanzi RE, Wasco W (1996) Alzheimer-associated presenilins 1 and 2: neuronal expression in brain and localization to intracellular membranes in mammalian cells. Nat Med 2:224-229.

Lange Y, Ye J, Rigney M, Steck T (2000) Cholesterol movement in Niemann-Pick type C cells and in cells treated with amphiphiles. J Biol Chem 275:17468-17475.

Liscum L, Ruggiero RM, Faust JR (1989) The intracellular transport of low-density lipoprotein-derived cholesterol is defective in NiemannPick type C fibroblasts. J Cell Biol 108:1625-1636.

Lusa S, Blom TS, Eskelinen EL, Kuismanen E, Mansson JE, Simons K, Ikonen E (2001) Depletion of rafts in late endocytic membranes is controlled by NPC1-dependent recycling of cholesterol to the plasma membrane. J Cell Sci 114:1893-1900.

Lütjohann D, Breuer O, Ahlborg G, Nennesmo I, Siden A, Diczfalusy U, Bjorkhem I (1996) Cholesterol homeostasis in human brain: evidence for an age-dependent flux of ${ }^{24} \mathrm{~S}$-hydroxycholesterol from the brain into the circulation. Proc Natl Acad Sci USA 93:9799-9804.

Naureckiene S, Sleat DE, Lackland H, Fensom A, Vanier MT, Wattiaux R, Jadot M, Lobel P (2000) Identification of HE1 as the second gene of Niemann-Pick C disease. Science 290:2298-2301.

Neufeld EB, Wastney M, Patel S, Suresh S, Cooney AM, Dwyer NK, Roff $\mathrm{CF}$, Ohno K, Morris JA, Carstea ED, Incardona JP, Strauss III JF, Vanier MT, Patterson MC, Brady RO, Pentchev PG, BlanchetteMackie EJ (1999) The Niemann-Pick C1 protein resides in a vesicular compartment linked to retrograde transport of multiple lysosomal cargo. J Biol Chem 274:9627-9635.

Orci L, Brown MS, Goldstein JL, Garcia-Segura LM, Anderson G (1984) Increase in membrane cholesterol: a possible trigger for degradation of HMG-CoA reductase and crystalloid endoplasmic reticulum in UT-1 cells. Cell 36:835-845.

Papini E, Gottardi E, Satin B, de Bernard M, Massari P, Telford J, Rappuoli R, Sato SB, Montecucco C (1996) The vacuolar ATPase proton pump is present on intracellular vacuoles induced by Helicobacter pylori. J Med Microbiol 45:84-89.

Pentchev PG, Comly ME, Kruth HS, Tokoro T, Butler J, Sokol J, Filling-Katz M, Quirk JM, Marshall DC, Patel S, Vanier MT, Brady RO (1987) Group C Niemann-Pick disease: faulty regulation of lipoprotein uptake and cholesterol storage in cultured fibroblasts. FASEB J 1:40-45.

Pol A, Luetterforst R, Lindsay M, Heino S, Ikonen E, Parton R (2001) A caveolin dominant negative mutant associates with lipid bodies and induces intracellular cholesterol imbalance. J Cell Biol 152:1057-1070.

Puglielli L, Konopka G, Pack-Chung E, MacKenzie Ingano LA, Berezovska O, Hyman BT, Chang TY, Tanzi RE, Kovacs DM (2001)
Acyl-coenzyme A:cholesterol acyltransferase modulates the generation of the amyloid $\beta$-peptide. Nat Cell Biol 3:905-912.

Refolo LM, Malester B, LaFrancois J, Bryant-Thomas T, Wang R, Tint GS, Sambamurti K, Duff KE, Pappolla MA (2000) Hypercholesteremia accelerates the Alzheimer's amyloid pathology in a transgenic mouse model. Neurobiol Dis 7:321-331.

Refolo LM, Pappolla MA, LaFrancois J, Malester B, Schmidt SD, Thomas-Bryant T, Tint GS, Wang R, Mercken M, Petanceska SS, Duff KE (2001) A cholesterol-lowering drug reduces $\beta$-amyloid pathology in a transgenic mouse model of Alzheimer's disease. Neurobiol Dis 8:890-899.

Riddell DR, Christie G, Hussain I, Dingwall C (2001) Compartmentalization of $\beta$-secretase (Asp2) into low-buoyant density, noncaveolar lipid rafts. Curr Biol 11:1288-1293.

Sakashita N, Miyazaki A, Takeya M, Horiuchi S, Chang CCY, Chang TY, Takahashi K (2000) Localization of human acyl-CoA:cholestero acyltransferase-1 in macrophages and in various tissues. Am J Pathol 156:227-236.

Scales SJ, Pepperkok R, Kreis TE (1997) Visualization of ER-to-Golgi transport in living cells reveals a sequential mode of action for COPII and COPI. Cell 90:1137-1148.

Simons M, Keller P, De Strooper B, Beyreuther K, Dotti CG, Simons K (1998) Cholesterol depletion inhibits the generation of $\beta$-amyloid in hippocampal neurons. Proc Natl Acad Sci USA 95:6460-6464.

Skovronsky DM, Doms RW, Lee VM (1998) Detection of a novel intraneuronal pool of insoluble amyloid $\beta$-protein that accumulates with time in culture. J Cell Biol 141:1031-1039.

Subtil A, Gaidarov I, Kobylarz K, Lampson MA, Keen JH, McGraw TE (1999) Acute cholesterol depletion inhibits clathrin-coated pit budding. Proc Natl Acad Sci USA 96:6775-6780.

Tabas I, Rosoff WJ, Boykow GC (1988) Acyl-coenzyme A:cholesterol acyltransferase in macrophages utilizes a cellular pool of cholesterol oxidase-accessible cholesterol as substrate. J Biol Chem 263:1266-1272.

Tienari PJ, De Strooper B, Ikonen E, Simons M, Weidemann A, Czech C, Hartmann T, Ida N, Multhaup G, Masters CL, van Leuven F, Beyreuther K, Dotti CG (1996) The $\beta$-amyloid domain is essential for axonal sorting of amyloid precursor protein. EMBO J 15:5218-5229.

Wolozin B, Kellman W, Rousseau P, Celesia GG, Siegel G (2000) Decreased prevalence of Alzheimer disease associated with 3-hydroxy3-methylglutaryl coenzyme A reductase inhibitors. Arch Neurol 57:1439-1443.

Xia W, Ray WJ, Ostaszewski BL, Rahmati T, Kimberly WT, Wolfe MS, Zhang J, Goate AM, Selkoe DJ (2000) Presenilin complexes with the C-terminal fragments of amyloid precursor protein at the sites of amyloid $\beta$-protein generation. Proc Natl Acad Sci USA 97:9299-9304.

Yamazaki T, Chang TY, Haass C, Ihara Y (2001) Accumulation and aggregation of amyloid $\beta$-protein in late endosomes of Niemann-Pick type C cells. J Biol Chem 276:4454-4460.

Zhang M, Dwyer NK, Neufeld EB, Love DC, Cooney A, Comly M, Patel $\mathrm{S}$, Watari H, Strauss III JF, Pentchev PG, Hanover JA, BlanchetteMackie EJ (2001) Sterol-modulated glycolipid sorting occurs in Niemann-Pick C1 late endosomes. J Biol Chem 276:3417-3425. 